\title{
Profitability Determinants in Indian Drugs and Pharmaceutical Industry: An Analysis of Pre and Post TRIPS Period
}

\author{
Shilpi TYAGI*, D. K. NAURIYAL ${ }^{* *}$
}

\begin{abstract}
This paper analyses the determinants of profitability of the Indian drug and pharmaceutical industry, which is known for historically weak innovative R\&D initiatives. The change in the economic environment brought out by the TRIPS compliance, this industry was found to have fast adjusted to new working environment by substantially modifying its strategies. The study uses inflation adjusted time-series data for a period 1990-2014 and applies OLS regression model with Newey-West standard errors. It has found that export intensity, A\&M intensity, and post-product patent regime have exercised positive influence on industries' profitability. The negative and statistically significant influence of Leverage ratio and operating expenditure to total assets ratio points to the need for firms to better their efficient management of funds, and contain costs. The study suggests that firms are required to pay far more attention to optimize their operating expenditures, advertisement and marketing expenditures and improve their export orientation, as part of the long term strategy.
\end{abstract}

Keywords: Patent rights, Indian Pharmaceutical Industry, Profits, TRIPS, Performance

JEL Code Classification: D21

UDC: $330.35: 339.724 .8$

DOI: https://doi.org/10.17015/ejbe.2016.017.01

\footnotetext{
*Corresponding Author, Senior Research Fellow, Department of Humanities and Social Sciences, Indian Institute of Technology Roorkee, Roorkee, India. Email: shilpityagi.iitr@gmail.com

** Professor, Department of Humanities and Social Sciences, Indian Institute of Technology Roorkee, Roorkee, India. Email:dk_nauriyal@yahoo.com
} 


\section{Introduction}

Profits are one of the key concepts in the industrial growth strategies because profits effect investment choices, growth of an industry and direction of trade and, therefore, make strong impact on capacity, productivity and efficiency (Uctum, 1995). The pharmaceutical industry is no exception to this common understanding enriched by ample theoretical and empirical research over the period of time. This industry, being technology and knowledge intensive, is driven more by thrust for innovations and inventions due to emergence of new/more aggressive variants of diseases on account of changing forms and profiles of viruses getting increasingly drug resistant. The specialty of the industry also lies in the fact that it is just not the drug but also drug delivery system that tends to influence efficacy of the drugs. These factors and ethical/legal parameters within which the drug industry has to operate have certainly added up to their costs which have already been too high. The R\&D and marketing cost considerations have also led to many mergers and acquisitions worldwide, including India. Thus profitability in this industry is governed by many more factors than what applies to other knowledge intensive industries.

Since the Indian pharmaceutical industry had never been R\&D oriented and has historically capitalized on the weak patent regime in India, profitability of this industry was largely governed by the production and marketing of fair quality yet low cost drug and formulations. The large domestic market and export competitiveness of this industry kept it firmly growing up. However, with TRIPS coming into existing, the economic and operational milieu for Indian drug and pharmaceutical industry (ID\&PI) has drastically changed. It may be noted that it is world's third-largest pharmaceutical industry in terms of volume yet stands ranked at $13^{\text {th }}$ position in terms of value (GOI, Annual Report 2014). The far lower rank, in terms of value, is reflective of the fact that Indian pharmaceutical companies are primarily operating in the low priced generic products group category with wide heterogeneity in firm sizes and product mix. These companies share around 72 per cent of Indian branded generic market (in terms of revenues), 19 per cent of overthe-counter (OTC) medicines and 9 per cent of patented drugs. Anti-infective drugs is credited with the largest share (16 per cent) of the Indian pharma market, followed by cardiovascular (13 per cent), gastro-intestinal (11\%). Remaining 60 per cent market is dotted by vitamins, minerals, respiratory, pain/analgesic, antidiabetic, and other medicines. In terms of value, exports of Indian pharmaceutical products registered a rise of CAGR of 26.1 per cent to touch USD15.6 billion in 2013-14(GOI, Annual Report 2014). Interestingly, the emergence of ID\&PI in the world pharmaceutical map can be attributed to the shift from product to process patent after 1970. These enabled the Indian pharmaceutical companies to reverseengineer and copycat the newest drugs launched in overseas markets through different processes, and market them in the domestic and overseas markets on very low prices. This particular step gave such a big push to ID\&PI that it emerged 
as one of the most profitable Indian manufacturing industries. However, the amended Patent Act, implemented since 2005, coupled with the Liberalization, Privatization and Globalization (LPG) policy reforms in 1991 opened up ID\&PI to new global challenges (Kiran \& Misra, 2011). While knowledge intensity and acquisitions became important factors for survival in the new strongly competitive and increasingly regulated environment at global level, there was a perceptible change in the strategies of Indian firms by adapting to utility models, contract R\&D and manufacturing, besides exercising options that were available to global firms. It may be noted that Indian pharmaceutical manufacturing facilities, approved by US Food and Drug Administration (FDA) as on March 2014 was the highest at 523 (approx. 37 per cent of total) for any country outside the US. The intensifying preferences for generic and bio-similar in regulated markets to combat rising health care costs, growing dossier-licensing and supply contracts with multinationals, enough capacity, and patent expiries, are the factors that are likely to keep Indian drug and pharmaceutical industry in good stead in times to come.

Since profitability is critical to survival and growth for any industry, it would be interesting to examine determinants of Profitability in ID\&PI for the period spanning from 1994 till 2014, when the indications for change in the operating environment started emerging and the change actually happened. One of the paradigm shift during the aforementioned change is spectacular rise in the R\&D expenses of Indian drug and pharmaceutical industry, especially that of top 20 firms. With this brief background information, rest of the paper is organized as follows. Section 2 discusses the overall scenario of the industry during pre and post-TRIPS periods. Section 3 encompasses description of databases, methodology and discussion on conceptual framework. Section 4 comprises results and discussions, while Section 5 concludes the study.

\section{Pre and post TRIPS Scenario in Indian D\&P Industry}

Indian pharmaceutical sector started emerging after 1970's Indian Patent Amendment Act. The process patent regime emanating after that amendment of 1970 had profoundly impacted the structure and growth of this industry by enabling Indian pharmaceutical firms to reverse-engineer the products and produce them, albeit through different processes. Consequently, by mid-1980s, this industry emerged as a major producer of pharmaceutical products, by developing rapidly in terms of products and price ranges $(\mathrm{CCl}, 2014)$. The fast growth in the share of Indian firms vis-à-vis MNCs with a phenomenal rise in the share of Indian companies from 20 per cent in 1970 to 80 percent by 2005 of the domestic market could be attributed to this movement from product to process patent, adaptability of Indian companies to this swift change and tightening of the government control on foreign entities. The leverage to reverse engineer and copycat the branded drugs and other proprietary pharmaceutical products without any significant R\&D, helped these companies to charge a much lower price, as compared to their foreign counterparts, and grab a large share of the market. However, WTO 
administered TRIPS (Trade Related Intellectual Property Rights) related obligations in 1995, ended this advantage. This forced them to reorient their survival and growth strategies by initiating serious R\&D activities apart from outreaching relatively untapped regulated markets of the West through expansion by ways of mergers, acquisitions, and undertaking foreign direct investment (Tyagi et. al., 2014; Vyas et al., 2012; Mishra \& Chandra, 2010; Pradhan, 2006; Chaudhary, 2005). This strategic shift, however, provided such a high stimulus to ID\&PI that the growth rate of pharmaceutical exports outweighed the growth rate of overall merchandise exports (Nauriyal \& Sahoo, 2008; Mahajan et al., 2015). A significant part of this growth story could be attributed to renewed interest of MNCs, as suggested by new product introductions, expansion in the field force and acquisition activities primarily due to the return of product patent, sturdy growth prospects of Indian economy, and attractiveness of India as a cost efficient production base. India's share in the global generics marketplace also bettered from 4.5 percent in 2006 to 10.3 percent by 2013. This appears to be noteworthy in view of the stiff competition from overseas generic drugs producers such as Teva, Mylan, Sandoz, etc. which have substantial share in the US pharmaceutical market with rich product pipelines across a wide range of therapeutic segments. However, it would be interesting to analyze trends in profitability along with R\&D and exports so as to find out if they have moved together. It may also help to draw lessons for the strategy reorientation, if required, at the national, industry and firm levels.

\subsection{Trends in Profits in Indian D\&P Industry}

The common understanding is that there could be a close association between profit and profit intensity per se, which is also borne by Figure 1. The year 2000 appears to be a threshold point after which there seems to be a constant rise in the profit as well as profit intensity.

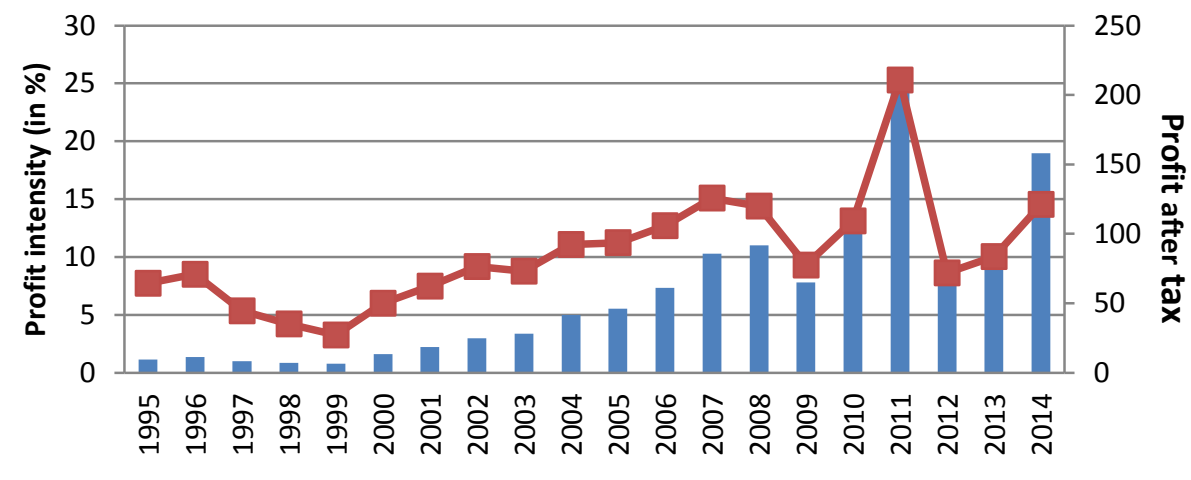

Figure 1: Profit after Tax and Profit Intensity in Indian Pharmaceutical Industry

Source: CMIE Prowess database, 2014 
The rise in foreign direct investment, contract manufacturing/outsourcing, value added joint ventures and overseas acquisitions, all buoyed by the TRIPs enforcement prospects since 1995, seem to be the prime reasons for the same (Ministry of Commerce and Industry, GOI, 2015). Greater focus on the export of generic drugs and specialty products to regulated markets such as US and Western markets by substantially enhancing front-end marketing capabilities, while conforming to quality and regulatory compliance of FDA, UK's MHRA, European Medicines Agency (EMA) and similar agencies have also helped in this regard (49 per cent of all drug master filings from India is registered with USFDA in 2013). As a consequence, its sales amplified from US \$6 billion in 2005 to US \$11.3 billion in 2011 and finally to US $\$ 20$ billion by 2015. The exceptional rise in profits in 2011 over 2010 can also be attributed to a massive $22 \%$ fall in the value of Rupee as big pharmaceutical companies earn their larger share of revenues from export markets.

Interestingly, a steep decline in the profit after tax and profit intensity of the pharmaceutical firms can be observed post 2011 with some signs of recovery after 2013. Increased competition and aggressive price pressures from MNCs in both the acute and chronic therapeutic segments, substantive rise in the field forces resulting in much expenditure on marketing, appeared to have contributed to this. The implementation of the National Pharmaceutical Policy 2012 by Govt. of India probably has also acted as an additional factor since it has resulted in margins erosion from $20 \%$ and $10 \%$ to $16 \%$ and $8 \%$ for retailers and stockists respectively (Confederation of Indian Industry, 2014).The rising concern over genuineness of clinical trial data of Indian pharmaceutical firms by USFDA, exacerbated by suspension of market approvals for 25 drugs by regulators in Europe in 2014 has also posed a serious challenge to them as these doubts and actions probably had resulted in significant loss of business. The brighter part is that Indian pharma industry has started initiating innovations such as developing combinational and controlled released products in-licensing and forging alliances with other Indian and foreign companies, besides improving operational efficiencies and building synergies.

It may also be worthwhile to examine if the grim economic outlook has also impacted Indian pharmaceutical industry throughout the study period. The relevant information is summed up in Figure 2.

Given that the correlation between sales revenue growth and GDP growth was weak ( $r=0.3093$ ), economic outlook for the economy did not seem to have been an important factor to exercise significant impact on the sales revenue of Indian pharmaceutical industry. It could possibly be so because rise in exports might have compensated for any slow growth in the domestic market. This appears to be plausible in view of the fact that exports constitute over 54 per cent of total turnover of the industry going up fromUSD7.8 billion in 2009 to USD 15.6 billion by 2013-14 (GOI, Annual Report 2014). 


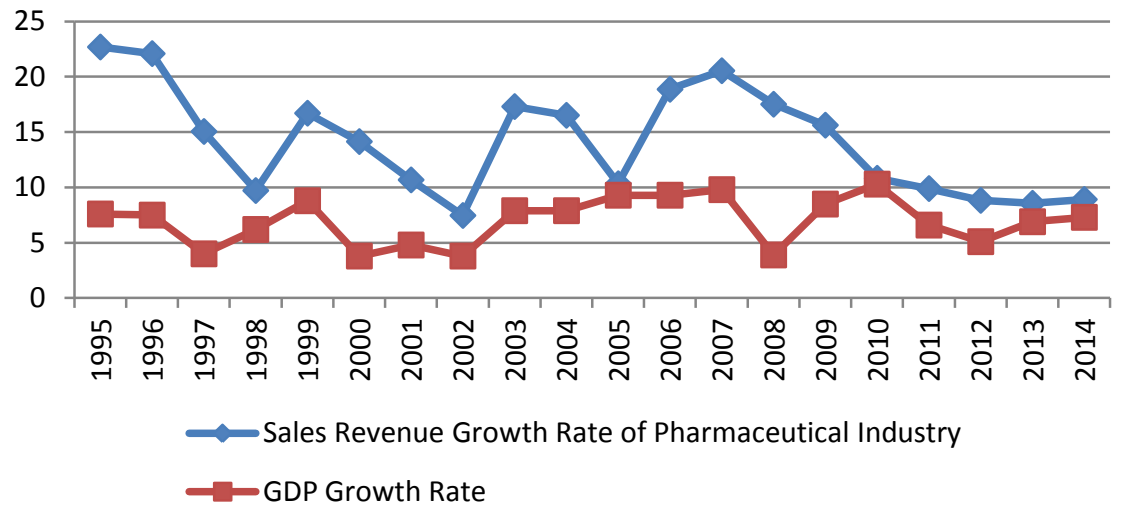

Figure 2: Growth Rates of India's GDP and Sales Revenue of Indian Pharmaceutical industry

Source: CMIE Prowess database, 2014 and RBI Handbook of Statistics on Indian Economy, 2014-15

\subsection{Trends in R\&D Expenditure of Indian D\&P Industry}

Although R\&D expenditure of Indian pharmaceutical firms was on the rise since 1995, especially after the signing of the TRIPs, yet it started picking up after the year 2000 and reached at 3 percent of total sales revenue by 2005 , as a sequel to major shift in their strategies from producing copycat drugs to innovative drugs. Figure 3 highlights relevant information in this regard.

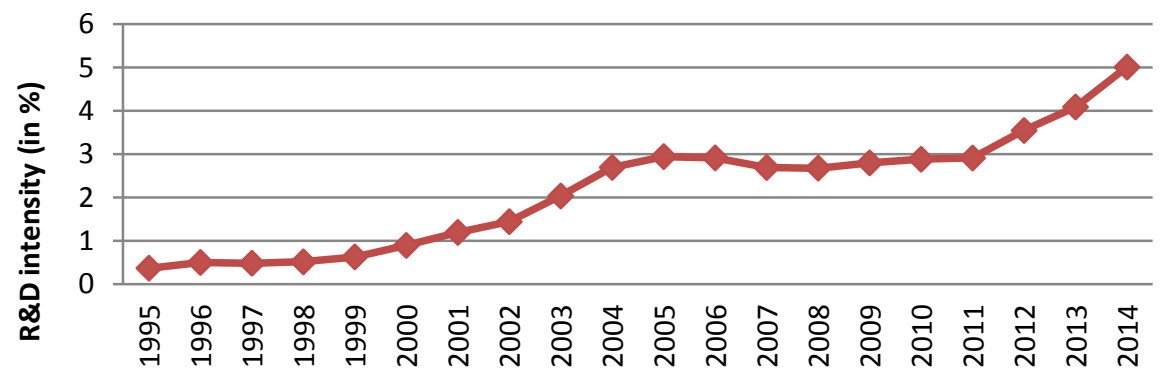

Figure 3: R\&D intensity in Indian pharmaceutical sector

Source: CMIE Prowess database, 2014

Nevertheless, there appears to be a deceleration in the growth of R\&D expenditure, especially after 2006, which can largely be attributed to the gloom set by the failure of out-licensed DRF 2725 and DRF 4148 by Dr. Reddy's Lab to Novo Nordisk and Novartis in 1998, and that of RBx 2258 by Ranbaxy to Schwarz Pharma in 2002. It had alerted other Indian pharmaceutical firms about the risks involved in 
Profitability Determinants in Indian Drugs and Pharmaceutical Industry: An Analysis of ...

the innovative R\&D. 'The Perlecan debacle' wherein the USD 52.2 million joint venture of Dr. Reddy's Lab, Citigroup Venture and ICICl venture in 2005 had collapsed in 2008 due to potential side effects of the molecules identified, further put a lid on such initiatives (Joseph, 2011).Interestingly, the R\&D efforts of Indian pharmaceutical companies have been found to have concentrated in chronic diseases such as cancer and diabetes, instead of tropical diseases viz., malaria, tuberculosis, etc. which afflict majority of the population in India and other developing economies (Joseph, 2011). The year 2004 was the starting point for the plethora of mergers and acquisition activities which appeared to be never part of the business strategies of the Indian drug and pharmaceutical firms. It gained acceleration and depth with time as is evident from Table 1.

Table 1. Select Acquisitions of Overseas Firms by Indian Pharmaceutical Firms

\begin{tabular}{|c|c|c|c|}
\hline Year & Target Company & Acquirer & Nature of Deal \\
\hline 2003 & C P Pharmaceuticals (UK) & Wockhardt & Acquisition for 15.6 million Euro \\
\hline 2004 & Trigenesis Therapeutics (US) & Dr. Reddy's Labs & Acquisition for USD11 million \\
\hline 2004 & Esparma (German) & Wockhardt & Acquisition for USD 11million \\
\hline 2004 & RPG Aventis (France) & Ranbaxy Lab & Acquisition for USD 70 million \\
\hline 2006 & $\begin{array}{l}\text { Betapharm Arzneimittel } \\
\text { GmbH (Germany) }\end{array}$ & $\begin{array}{l}\text { Dr Reddy's } \\
\text { Laboratories }\end{array}$ & Acquisition for USD 597 million \\
\hline 2005 & Docpharma NV (Belgium) & Matrix Lab. & Acquisition for USD 263 million \\
\hline 2006 & Terapia (Romania) & Ranbaxy Laboratories & Acquisition for USD 324 million \\
\hline 2007 & NegmaLerads (France) & Wockhardt Ltd. & Acquisition for USD 265 million \\
\hline 2007 & $\begin{array}{l}\text { Morton Grove } \\
\text { Pharmaceuticals (US) }\end{array}$ & Wockhardt Ltd. & Acquisition for USD 38 million \\
\hline 2007 & Hollister-Stier Labs (US) & Jubilant Organosys Ltd. & Acquisition for USD 122 million \\
\hline 2008 & Draxix Health Inc. (Canada) & Jubilant Organosys Ltd. & Acquisition for USD 262 million \\
\hline 2008 & Axicorp (German) & Biocon & $\$ 30$ million \\
\hline 2011 & I'rom Pharmaceuticals (Japan) & Lupin & Undisclosed \\
\hline 2011 & $\begin{array}{l}\text { Bremer Pharma GmbH } \\
\text { (Germany) }\end{array}$ & ZydusCadila & Acquisition for USD million \\
\hline 2011 & Nesher Pharma (US) & ZydusCadila & Acquisition for USD 60 million \\
\hline 2011 & $\begin{array}{l}\text { GSK's Penicillin manufacturing } \\
\text { facility (US) }\end{array}$ & Dr Reddy's Labs. & Acquisition for USD 20 million \\
\hline 2011 & Onyx Research Chemicals & IPCA Labs & Acquisition for USD 7.39 million \\
\hline 2012 & DUSA (US) & Sun Pharmaceuticals & Acquisition for USD 230 million \\
\hline 2013 & OctoPlus (Netherlands) & Dr Reddy's Labs. & Acquisition for USD 36.6 million \\
\hline 2014 & Natrol Inc. (US) & Aurobindo Pharma & Acquisition for USD 132.5 million \\
\hline
\end{tabular}

Source: Mahajan, Varun., 2015 'Trade Performance, Efficiency and Productivity of Indian Drug and Pharmaceutical Industry' unpublished Ph. D. dissertation at IIT Roorkee.

The most remarkable change, nevertheless, is evident after 2010 when the firms started investing far more resources towards R\&D activities, as part of the strategic shift, induced by changing business environment. Some of the firms, especially large-sized, started focusing on Novel Drug Delivery Systems (NDDS), and 
expanding production facilities by importing latest capital goods and seeking technology transfer.

\subsection{Trends in Exports of Indian D\&P Industry}

Interestingly, exports have been the mainstay of most of the Indian pharmaceutical firms in the organized sector. As is evident from Table 2, the share of export revenue in the total sales revenue has been continuously on the rise.

Table 2. Export Revenue as a Percentage of Total Sales Revenue

\begin{tabular}{cccc}
\hline Year & Percentage & Year & Percentage \\
\hline 1995 & 17.71 & 2005 & 32.47 \\
1996 & 18.29 & 2006 & 36.39 \\
1997 & 19.88 & 2007 & 36.89 \\
1998 & 18.49 & 2008 & 39.22 \\
1999 & 19.54 & 2009 & 38.75 \\
2000 & 21.86 & 2010 & 38.89 \\
2001 & 25.23 & 2011 & 43.12 \\
2002 & 28.93 & 2012 & 47.42 \\
2003 & 31.20 & 2013 & 51.30 \\
2004 & 32.14 & 2014 & 54.20 \\
\hline
\end{tabular}

Source: CMIE Prowess Database, 2014

Profitability of the export market has also gone up for the fact that that over 40 per cent of drugs i.e., 680 formulations spread over 27 therapeutic segments, including serious diseases such as HIV, diabetes, heart diseases, cancer marketed in India, have been brought under price control (as part of National List of Essential Medicines) by Government of India by the end of 2014(GOI Annual Report, 2014). Overseas markets, on the other hand, are largely free from such controls, making them far more lucrative. The exports were further bolstered, more so in the regulated markets, by the fact that Indian pharma companies started taking advantage of off-patenting of a large number of patented drugs in 2007 which was furthered by observance of quality compliance and good manufacturing practices (GMP) within the regulatory frameworks of Food and Drug Administration (FDA) and European Medicines Agency (EMA) by the Indian firms. The export intensity of Indian firms has always been on the rise with the onset of this millennium, as is highlighted in Figure 4. Figure 4 also brings to the fore that while there has been an upsurge in the growth of exports intensity as a whole after 2000, it tapered off after 2009. Interestingly, despite competitive advantage in generic markets, only one firm in India namely, Ranbaxy stood at the $9^{\text {th }}$ position among top ten global generic players in 2012 (GOI, 2012). Post 2011, export intensity demonstrated a rapid increase because of weakening Rupee, increasing off-patenting and increased mergers and acquisitions activities. 


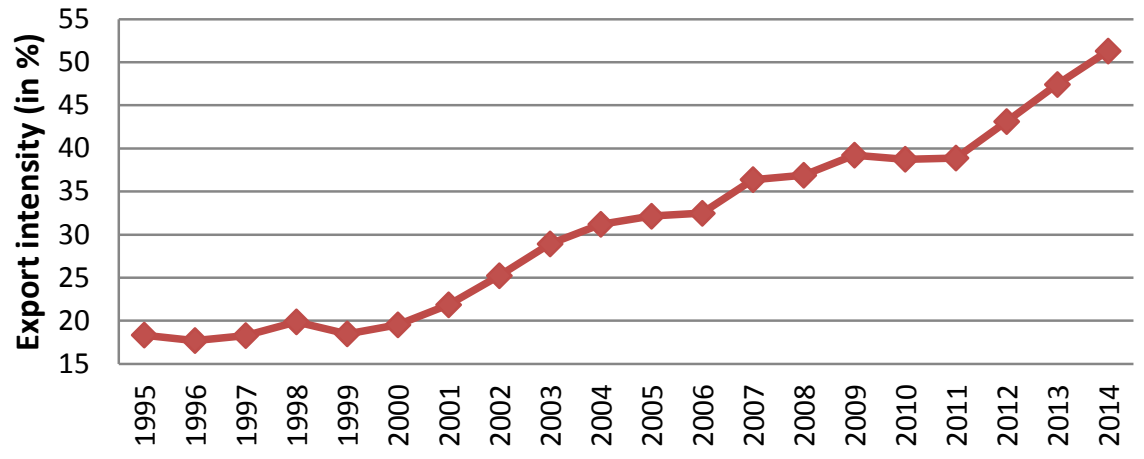

Figure 4. Export intensity in Indian pharmaceutical sector

Source: CMIE Prowess database, 2014

After having discussed pre and post TRIPS scenario of Indian Drug and pharmaceutical industry, it would be interesting to analyze the profitability of Indian drug and pharmaceutical industry to develop an insight into the profitability determinants of this industry.

\section{Database, Methodology and Conceptual Framework}

\subsection{Data Sources}

The study uses real financial data from the audited annual financial statements for Indian pharmaceutical industry for a period 1989-2014. The study uses time series data taking aggregate values for all the Indian pharmaceutical firms listed in Prowess Database of Center for Monitoring Indian Economy (CMIE). This time span has been taken to examine the profitability determinants' dimensions of this industry in the pre (1989-2004) and post-patent (2005-2014) time periods. This study is the most recent attempt made to analyze the profitability determinants of Indian D\&P industry. Earlier study by Mazumdar (2013) was limited to data till 2006.

\subsection{Conceptual Framework}

The subject of the conceptualization of determinants of profits is of greater research interest as such studies may help policy makers and managers to devise and implement public/company specific policies that may stimulate and support the management strategies to maximize profits in this dynamic and globally competitive industry which is historically known to be gaining high profits by producing copycats of the drugs, primarily developed and marketed in the west.

The dependent variable in our study is the profit of Indian D\&P industry measured as Return on Assets (ROA). This measure is an indicator of how efficient the 
management of a firm is, in generating income from the assets, employed by the firm. Various studies namely, Kuntluru et al., (2008); Prasetyantoko and Parmono (2008); Stierwald (2010); Berger et. al (2014); San and Heng (2011); Vijayakumar (2011) and Adjei (2012) have taken ROA as a measure of profitability in their studies. It is calculated as a ratio of net income to total assets in the given year.

Table 3 presents and defines the list of dependent and independent variables that are postulated to be affecting the profitability in ID\&PI.

Table 3. Determinants of Profits in Indian D\&P industry

\begin{tabular}{|c|c|c|}
\hline Variables & Symbols & Description \\
\hline \multicolumn{3}{|l|}{ Dependent Variable } \\
\hline Return on Assets & ROA & $\begin{array}{l}\text { Net Income as a percentage of total assets in } \\
\text { the given year }\end{array}$ \\
\hline \multicolumn{3}{|l|}{ Independent Variables } \\
\hline Export Intensity & $X I$ & $\begin{array}{l}\text { Exports as a percentage of total sales in the } \\
\text { given year }\end{array}$ \\
\hline Leverage Ratio & LR & $\begin{array}{l}\text { Total debt as a percentage of total assets in } \\
\text { the given year }\end{array}$ \\
\hline $\begin{array}{l}\text { Advertising and Marketing } \\
\text { (A\&M) Intensity }\end{array}$ & AMI & $\begin{array}{l}\text { Advertising and Marketing expenditure as } \\
\text { percentage of total sales in the given year }\end{array}$ \\
\hline R\&D Intensity & RDI & $\begin{array}{l}\text { R\&D expenditure as percentage of total sales } \\
\text { in the given year }\end{array}$ \\
\hline Capital Intensity & $\mathrm{KI}$ & $\begin{array}{l}\text { Net fixed assets as percentage of total sales in } \\
\text { the given year }\end{array}$ \\
\hline $\begin{array}{l}\text { Operating Expenditure to } \\
\text { Total Assets Ratio }\end{array}$ & OER & $\begin{array}{l}\text { Operating expenditure as percentage of total } \\
\text { assets in the given year }\end{array}$ \\
\hline $\begin{array}{l}\text { Time dummy for stronger } \\
\text { patent regime }\end{array}$ & PATENTDUM & $\begin{array}{l}\text { Dichotomous variable with value } 1 \text {, if time } \\
\text { period is after } 2005,0 \text { otherwise }\end{array}$ \\
\hline
\end{tabular}

Variables in Table 3 are briefly described below.

Export Intensity: Bernard and Jensen (1995), in their path breaking research, investigated the relation between exports performance and productivity. Later on Wagner (2007) studied the links between export, productivity and profitability. His 'learning by exporting' theory demonstrates that highly productive exporters gain higher profitability. Some studies have reported that export intensity is directly associated with profitability (Beleska-Spasova et al., 2002; Vogel \& Wagner, 2011; Wagner, 2012 and Vu et al., 2014), though there is no dearth of studies which have found this relationship to be inconclusive in nature (Kongmanila et al., 2009 and Grazzi, 2010). Nevertheless, openness allows an industry to be benefited from increased return by being globally competitive (Zimmerman, 1987). In India's context, the overseas markets are far more rapidly expanding due to promotion of generics on account of steep rise in the health costs and a fast ageing population in the west. The rising exports may have not only provided Indian firms with much needed resources for upgrading their products and management practices but also 
the needed incentive to do so as to meet the regulatory and other requirements for exports. Thus basing upon a common notion of exporting firms being more profitable and drawing from the prior art, it is hypothesized that export intensity may have positive impact on the profitability.

Leverage Ratio: An industry with higher leverage ratio is at greater financial risk as compared to another industry with lower leverage ratio. Packing order theory suggests that competitive firms in any industry prefer to use internal financing than using external debt. Existing research indicates that firms have low debt because they operate in industries with high degree of business risk and thus expect a negative relation between leverage and profitability (Athanasoglou et al., 2008; Mohapatra, 2012 and Sun et al., 2013). However, the impact of financial variables on a given firm's profitability has not been clearly established in the literature (Oustapassidis, 1998; Vassiliou \& Frangouli, 2000), as evidences have appeared on both the sides. While some studies have found leverage ratios exercising positive impact on firm's profitability (Gale, 1972; Vassiliou \& Frangouli, 2000), other studies have found negative impact (Baker, 1973; Hurdle, 1974 and Zubairi, 2010). Thus, in order to capture the effect of leverage on the industrial profitability, total debt as a percentage of total assets, in the given year, is included in the model. It is hypothesized that leverage ratio has negative impact on profitability.

Advertising and Marketing Intensity: Advertising and marketing enhance brand recognition and create a reputation premium for the firms which enables firm to fetch a higher price relative to competing products that may be similar in terms of physical characteristics. Research studies undertaken over a period of time suggest a positive relationship between advertising expenditure and profitability (Bhagwat \& Bruine, 2011). Few studies, however, have also reported this relationship to be a negative and insignificant (Comanor et al., 1972). To study the effect of advertising on profitability with reference to pharmaceutical industry is very important because this industry follow typical model of advertising. It invests heavily in making direct contacts to medical practitioners and chemists as they can help in manipulating demand to a greater degree, and secondly, it also targets direct consumers to create a brand image to reap out the benefit of loyalty. Basing upon prior art, it is hypothesized that advertising and marketing intensity positively impact the profitability.

R\&D Intensity: Existing literature indicates that R\&D expenditure of a pharmaceutical firm affects its profitability positively. The explanation to this postulation lies in the fact that reason for conducting R\&D is to generate profits which in turn may support further R\&D expenditure and keeps firm in the forefront. The linkage from profits to $R \& D$ expenditure was reported to be direct since it concerns yearly budget decisions and can be captured by the yearly variations. Earlier studies indicate that $R \& D$ expenditure has a positive influence and affect profitability appreciably in pharmaceutical firms (Simanjutak et al., 2011) owing to the possibility that R\&D leads to innovative products, which, depending upon their reception in the market, may add tremendously to company's profits 
(Scherer, 2001). However, few research studies have also reported a negative relationship between firm level profitability and $R \& D$ expenditure owing to the possibility that when firms decide to go for such long term investment, they forego some current investment and stock market results that may show unfavorable impact. Theoretically, endogenity has also been confirmed between R\&D expenditure and profit related variables (Malmberg, 2008). Present study also presupposes, based on the findings of empirical literature in this regard, a positive impact of R\&D on profitability.

Capital Intensity: High capital intensity demonstrates large sunk costs and possibly acts as a barrier to entry into the industry (Mc Donald, 1999 and Demir 2013). Existing literature suggests the positive and significant impact of capital intensity on industrial profitability (Fenny, 2000; Glen et al., 2001; Kambhampati \& Parikh, 2003). The effect of capital intensity in these studies has been accounted for, by using net fixed assets as percentage of total sales in the given year. Thus, it is hypothesized that higher capital intensity, represented by net fixed assets as percentage of total sales in the given year, leads to higher profitability.

Operating Expenditure to Total Assets Ratio: Operating expenses to total assets ratio is a measure of management efficiency which demonstrates the quality of management (Abreu \& Mendes, 2001; Molyneux \& Thorton, 1992). Managerial performance exhibited in qualitative terms such as organizational discipline, control systems, quality of staff etc., can be expressed as financial ratios (Ongore et al., 2013). Higher operating expenses lead to lower profits and vice versa (Bourke, 1989). Research studies, in this regard, have reported negative impact of the ratio of operating expenses to total asset on the profitability (Athanasoglou et al., 2005; Said \& Tumin, 2011). It has further been reported that the higher operating costs exhibit lower competitive pressure in an industry (Flamini et al., 2009). Thus, in this study, we assume relationship between operational costs and industrial profitability to be negative. This study includes 'operating expenses to total assets ratio' as an explanatory variable to explore the relationship between operational efficiency and profitability of ID\&PI.

Time Dummy for Stronger Patent Regime: Stronger patent regime is expected to force the firms to commit part of their earnings for further inventions and innovations, which in turn may help them to earn more profit by using utility models in the short run and breakthrough innovations in the long run. However, stronger protection of IPRs may also have negative impact on the profitability as it may deprive the firms from any opportunity to replicate the patented drugs. The effect of stronger patent regime, in this study has been accounted for, through the application of dichotomous variable i.e., attributing the value of 1 for period after 2005,0 otherwise. It is hypothesized that stronger patent regime may have positive impact on profitability of the firm. 
Profitability Determinants in Indian Drugs and Pharmaceutical Industry: An Analysis of ...

\subsection{Methodology}

In order to study the macro determinants of profits Indian D\&P industry, the study uses simple OLS regression and follows the Newey-West procedure to deal with the problems of autocorrelation and heteroskesdasticity. Collinearity diagnostics confirmed high colliniearity between RDI and XI variables, therefore, alternate models are formulated by dropping RDI and keeping XI variable and vice versa. Two econometric specifications have been estimated to investigate the determinants of profitability in the Indian D\&P industry for three time periods i.e., for (i) an extended time period of 25 years spanning from 1989 to 2014, (ii) 1989-90 to 200304 (pre-product patent regime), and (iii) 2004-05 to 2013-14 (post-product patent regime). The last two sub-periods have been taken to examine if there was any change in direction, degree and magnitude of profitability determinants as a sequel to enforcement of TRIPS provisions.

The Model specifications are as follows:

Models 1, 3 and 5:

$$
R O A_{t}=\alpha+\beta_{1} X I_{t}+\beta_{2} L R_{t}+\beta_{3} A M I_{t}+\beta_{4} K I_{t}+\beta_{5} O E R_{t}+\beta_{6} P A T E N T D U+\varepsilon_{t}
$$

Models 2, 4 and 6:

$$
R O A_{t}=\alpha+\beta_{1} L R_{t}+\beta_{2} A M I_{t}+\beta_{3} R D I_{t}+\beta_{4} K I_{t}+\beta_{5} O E R_{t}+\beta_{6} P A T D U M+\varepsilon_{t}
$$

\section{Results and Discussions}

Descriptive statistics of all the variables are presented in Table 4.

Table 4. Descriptive statistics for 25 Observations of the Variables (19902014)

\begin{tabular}{lcccc}
\hline Variable & Mean & Std. Dev. & Min & Max \\
\hline ROA & 43.17 & 14.22 & 21.70 & 63.82 \\
LR & 26.61 & 4.15 & 20.67 & 36.01 \\
XI & 29.44 & 11.99 & 15.23 & 54.20 \\
AMI & 6.00 & 0.78 & 4.94 & 8.12 \\
RDI & 1.83 & 1.37 & 0.33 & 5.01 \\
OER & 71.05 & 12.77 & 51.83 & 88.56 \\
KI & 29.87 & 4.96 & 18.21 & 36.55 \\
\hline
\end{tabular}

Source: Authors' calculations, CMIE Prowess Database, 2014

An empirical analysis was carried out with an estimation of the specified econometric models to find out the determinants of profits in ID\&PI. However, before proceeding to the estimation, the data were examined for the nonstationarity and unit root of the times series and Augmented Dickey-Fuller (ADF) and Kwiatkowski-Phillips-Schmidt-Shin (KPSS) were estimated. The results are presented in Table 5. 
Table 5. Test statistics for Fisher-type unit-root test based on Augmented Dickey Fuller (ADF) and Kwiatkowski-Phillips-Schmidt-Shin (KPSS) Tests for Model 1 and Model 2

\begin{tabular}{|c|c|c|c|c|}
\hline $\begin{array}{l}\text { Unit root } \\
\text { tests }\end{array}$ & $\begin{array}{r}\text { Augmente } \\
\text { with t }\end{array}$ & $\begin{array}{l}\text { Dickey-Fuller } \\
\text { me trend }\end{array}$ & & KPSS Test with time trend \\
\hline Variables & $\begin{array}{l}\text { ADF Test } \\
\text { Statistics }\end{array}$ & Interpretation & $\begin{array}{l}\text { KPSS Test } \\
\text { Statistics }\end{array}$ & Interpretation \\
\hline ROA & -0.26 & Unit root & $0.24^{* *}$ & time trend with non-stationary errors \\
\hline$\triangle R O A \#$ & $-4.73 *$ & No unit root & 0.12 & time trend with stationary errors \\
\hline $\mathrm{XI}$ & 1.2 & Unit root & $0.11 *$ & time trend with non- stationary errors \\
\hline$\Delta \mathrm{XI} \#$ & $-2.92^{*}$ & No unit root & 0.09 & time trend with stationary errors \\
\hline LR & -2.24 & Unit root & $0.42 *$ & time trend with non-stationary errors \\
\hline$\Delta \mathrm{LR \#}$ & $-3.28 *$ & No unit root & 0.26 & time trend with stationary errors \\
\hline AMI & $-2.88 *$ & No unit root & $0.22 * *$ & time trend with non- stationary errors \\
\hline$\Delta$ AMI\# & $-5.78^{*}$ & No unit root & 0.06 & time trend with stationary errors \\
\hline $\mathrm{RDI}$ & 0.25 & Unit root & 0.18 & time trend with stationary errors \\
\hline$\Delta \mathrm{RDI} \#$ & $-1.77^{* *}$ & No unit root & 0.95 & time trend with stationary errors \\
\hline $\mathrm{KI}$ & $-3.59 *$ & No unit root & 0.16 & time trend with stationary errors \\
\hline$\Delta \mathrm{KI} \#$ & $-3.43^{*}$ & No unit root & 0.91 & time trend with stationary errors \\
\hline OER & -0.15 & Unit root & $0.13^{* *}$ & time trend with non- stationary errors \\
\hline$\triangle \mathrm{OER \#}$ & $-4.62 *$ & No unit root & 0.14 & time trend with stationary errors \\
\hline
\end{tabular}

Note: (I ) \# First order difference of specified variable is taken. (ii) All tests use one lag. (iii) * and** and indicates significance at $1 \%$ and $5 \%$.

Source: Authors' calculations, CMIE Prowess Database, 2014

All the variables are found containing no unit roots at first order difference. All the models were, therefore, estimated on the first order differentiated variables. Table 6.1 and 6.2 highlight the relevant results. The reported $\mathrm{F}$ statistics for all models depict that the estimated models are statistically significant. Significance and performance of individual independent variables are discussed below.

Export Intensity shows a positive and significant relationship with pharmaceutical profits in all the models suggesting that export intensity has exercised positive impact on the profitability of the firms. The most plausible explanation could be that exports not only offer much more remunerative prices as compared to domestic market but also induce firms to adopt the best manufacturing practices and upgrade product quality to the global standard that in the long run help them to significantly improve products portfolio and have access to many more markets apart from gaining access to finance and state-of-art technology.

Leverage ratio confirms negative yet insignificant association with industrial profits. This result is consistent with existing research findings (Athanasoglou et al., 2008; Mohpatra, 2012; Sun et al., 2013). 
Profitability Determinants in Indian Drugs and Pharmaceutical Industry: An Analysis of ...

\begin{tabular}{|c|c|c|}
\hline Different estimation models & \multicolumn{2}{|c|}{ Estimated values for the entire study period (1989-2014) } \\
\hline Independent variables & Model-1 & Model-2 \\
\hline \multicolumn{3}{|c|}{ Panel A : Estimated Coefficients } \\
\hline \multirow{2}{*}{$\Delta \mathrm{XI}$} & $0.24264 * *$ & \multirow[b]{2}{*}{ - } \\
\hline & $(0.22959)$ & \\
\hline \multirow{2}{*}{$\Delta \mathrm{LR}$} & -0.33291 & -0.27231 \\
\hline & $(0.27632)$ & $(0.18301)$ \\
\hline \multirow{2}{*}{$\Delta \mathrm{AMI}$} & $1.64053 * * *$ & $1.39705^{* *}$ \\
\hline & $(0.83851)$ & $(0.64566)$ \\
\hline \multirow{2}{*}{$\Delta \mathrm{RDI}$} & 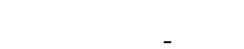 & $0.62708 * *$ \\
\hline & - & $(0.60212)$ \\
\hline \multirow{2}{*}{$\Delta \mathrm{KI}$} & $0.66218 * *$ & 0.29116 \\
\hline & $(0.20921)$ & $(0.11798)$ \\
\hline \multirow{2}{*}{$\triangle \mathrm{OER}$} & $1.03880^{* * *}$ & 0.81273 \\
\hline & $(0.15818)$ & $(0.07727)$ \\
\hline \multirow{2}{*}{ PATENTDUM } & $0.61447^{* *}$ & $0.71196 * *$ \\
\hline & $(0.26564)$ & $(0.59665)$ \\
\hline
\end{tabular}

\begin{tabular}{ccc}
\hline \multicolumn{3}{c}{ Panel B: Test Statistics } \\
\hline \multirow{2}{*}{ F statistic } & \multicolumn{3}{c}{$\mathrm{F}(6,18)$} \\
\cline { 2 - 3 } & $161.36^{* * *}$ & $158.35^{* * *}$ \\
\hline
\end{tabular}

No. of observations 25

Note: (i) \# First order difference of specified variable is taken. (iii) *** and ${ }^{* *}$ indicate significance at $1 \%$ and 5\%. Source: Authors' estimations, CMIE Prowess Database, 2014

Advertising and marketing ( $A \& M)$ intensity demonstrates a positive and significant relationship with profits in all models. This finding implies that in the advertisedintensive Indian D\&P industry, higher expenditure on A\&M helps the companies to get mind space of medical practitioners and patients which may boost up sales, and consequently profitability. The impact of A\&M on firm's profitability has already been explained much and the literature overwhelmingly suggests the positive influence of $A \& M$ on profitability. Interestingly this relationship turns out stronger in model 3 and 4 than other model variants. It implies that firms were more heavily relying on advertising for brand value creation than R\&D investment in pre- TRIPS period.

As per expectations, $R \& D$ intensity has exercised a positive and significant influence on ROA. The investment in R\&D was expected to improve innovation capacity of the firms leading to increase in the products range and products type, which become highly critical in intensely competitive market for branded generics. The expenditure on technology up-gradation necessitated by FDA approval requirements for export markets might have further enhanced the marketing success of the firms leading to better profitability. The R\&D angle is somewhat new to Indian pharmaceutical firms which, prior to 1995, were known more for producing copycats than innovative pharma products. The strong value for R\&D 
coefficient in post TRIPS period implies that Indian pharmaceutical industry started investing more in R\&D post-2005 in order to comply with changed market dynamism.

\begin{tabular}{|c|c|c|c|c|}
\hline \multirow{2}{*}{$\begin{array}{l}\text { Different } \\
\text { estimation } \\
\text { models } \\
\text { Independent } \\
\text { variables }\end{array}$} & \multicolumn{2}{|c|}{$\begin{array}{l}\text { Estimated values for Pre-TRIPS } \\
\text { amendment Act, } 2005 \text { (1989-2004) }\end{array}$} & \multicolumn{2}{|c|}{$\begin{array}{l}\text { Estimated values for } 2005-2014 \text { (Post- } \\
\text { TRIPS Patent amendment act, 2005) }\end{array}$} \\
\hline & Model-3 & Model-4 & Model-5 & Model-6 \\
\hline \multicolumn{5}{|c|}{ Panel A : Estimated Coefficients } \\
\hline$\Delta \mathrm{XI}$ & $\begin{array}{l}0.28834 * * \\
(0.11167)\end{array}$ & - & $\begin{array}{c}0.08870^{* *} \\
(.21142)\end{array}$ & - \\
\hline$\Delta \mathrm{LR}$ & $\begin{array}{l}-0.31936 \\
(0.26543)\end{array}$ & $\begin{array}{l}-0.26042 \\
(0.20431)\end{array}$ & $\begin{array}{l}-0.32109 \\
(0.30125)\end{array}$ & $\begin{array}{l}-0.30064 \\
(0.29044)\end{array}$ \\
\hline$\Delta \mathrm{AMI}$ & $\begin{array}{c}2.12422^{* * *} \\
(.33381)\end{array}$ & $\begin{array}{c}2.31552 * * * \\
(0.36566)\end{array}$ & $\begin{array}{c}1.39504 * * * \\
(1.11001)\end{array}$ & $\begin{array}{c}1.3444 * * * \\
(1.0957)\end{array}$ \\
\hline$\Delta \mathrm{RDI}$ & - & $\begin{array}{c}0.70314^{* *} \\
(0.64197)\end{array}$ & - & $\begin{array}{l}1.03167^{* *} \\
(0.30351)\end{array}$ \\
\hline$\Delta \mathrm{KI}$ & $\begin{array}{c}0.62019 * * \\
(0.38365)\end{array}$ & $\begin{array}{l}0.30178^{*} \\
(0.08428)\end{array}$ & $\begin{array}{c}0.63961 * * \\
(0.29123)\end{array}$ & $\begin{array}{c}0.28150 \\
(0.19059)\end{array}$ \\
\hline$\triangle \mathrm{OER}$ & $\begin{array}{c}0.63381 * * * \\
(0.07878)\end{array}$ & $\begin{array}{c}0.80048 \\
(0.07854)\end{array}$ & $\begin{array}{c}0.85995 \\
(0.09188)\end{array}$ & $\begin{array}{c}0.88155^{* *} \\
(0.12042)\end{array}$ \\
\hline
\end{tabular}

\begin{tabular}{|c|c|c|c|c|}
\hline \multicolumn{5}{|c|}{ Panel B: Test Statistics } \\
\hline \multirow[t]{2}{*}{ F statistic } & \multicolumn{2}{|c|}{$F(5,9)$} & \multicolumn{2}{|c|}{$F(5,4)$} \\
\hline & $80.34 * * *$ & $71.21 * * *$ & $51.30 * * *$ & 53.85 \\
\hline
\end{tabular}

No. of observations 15 10

Note: (i) \# First order difference of specified variable is taken. (iii) *** and** indicate significance at $1 \%$ and 5\%. Source: Authors' estimations, CMIE Prowess Database, 2014

Capital intensity exhibits positive yet insignificant association with pharmaceutical profits in model 2, 3 and 6 but turns out significant with positive sign when the RDI variable is dropped. Earlier studies have also reported similar findings (Demir, 2013; Fenny, 2000; Spaventa, 1970). Insignificance of this relationship may be due to the low capital intensity and its' probable collinearity with RDI. Although, capital investment in Indian D\&P industry is increasing over the years but pharmaceutical sector, as a whole, is found to be much less capital intensive as compared to the other segments of manufacturing sector (Mazumdar, 2013).

Operating Expenditure to Total Assets Ratio exhibits significant relationship with profits in Indian D\&P industry when RDI variable is dropped. It validates the efficiency theory that stipulated that manufacturing entities can earn more profits if they are more efficient in their operations than their competitors (Olweny \& Shipo, 2011). It appears that higher operational efficiency in Indian pharmaceutical 
Profitability Determinants in Indian Drugs and Pharmaceutical Industry: An Analysis of ...

industry has led to higher competitiveness which has furthermore increased exports and overseas profits.

Stronger patent regime dummy (PATENTDUM) has emerged as significant variable exercising positive impact on the profitability of the pharmaceutical firms. It implies that post-TRIPS, stronger patent protection have improved profitability of Indian pharmaceutical firms. It appears to be contrary to the popular belief that stronger patent protection may severely damage the competitive strength of Indian drug and pharmaceutical firms. It also entails that Indian firms have been able to adapt to radical change in the global economic environment by engaging in contract $R \& D$, dossier-licensing, supply contracts with multinationals, along with enough ready capacity etc.

Pre-TRIPS (models 3 and 4) and post-TRIPS (models 5 and 6) regression models do not show much difference in sign, value and significance of the estimated coefficients. The negligible difference in the results could also be attributed to the difference in overall time period. Interestingly, when we compare the pre and postpatent regime, the estimated coefficient of R\&D intensity turned out as the most important determinant in post TRIPS regime. Thus new patent regime has introduced some improvement in general R\&D activity in Indian pharmaceutical sector though the firms started gearing for a remarkable rise in the R\&D expenses due to the introduction of product patent regime by January 1,2005 , alongside technological up gradation in order to meet FDA related export requirements. Overall, the industry witnessed same direction of relationships among independent and dependent variables progress in most of the study period. It is generally believed that this change scenario would have long term impact than the shortterm impact.

\section{Conclusions and Policy Implications}

Present study has found that export intensity, $A \& M$ intensity, R\&D intensity and post-patent era have exercised positive influence on profitability. All these factors are important because they provide powerful tools to the firms to improve their performance and profitability by expanding to overseas markets, raising $A \& M$ expenditure productively even under strong patent protection regime. The negative and statistically significant influence of leverage ratio, and operating expenditure to total assets ratio points to the need for firms to improve fund management efficiency, and contain costs. It may be mentioned that while external factors such as exports and economic environments are not within the control of the firm, it could always enhance its revenue generating capacity by working far more pragmatically on $A \& M$ and operating expenditures, and debts. However, firm is likely to gain more in the long term if it has significant export orientation by addressing the issues such as strict compliance to good manufacturing practices and quality. It would increase importers' confidence in the drugs manufactured in India. 
The future research could focus on some approaches which are not considered in this study. Firstly, some other variables including impact of mergers and acquisitions and pricing policies along with changes in regulatory framework may be considered for analyzing the profits in Indian D\&P industry. Types of R\&D activities undergoing in this industry may also be analyzed to find out linkages between RDI, AMI and pricing policies. Secondly, two way relationships may also be studied in terms of profits and RDI; and profits and exports.

\section{References}

Abreu, M., \& Victor M. (2001). Commercial bank interest margins and profitability: evidence from some EU countries. The Pan-European Conference Jointly Organised by the IEFS-UK \& University of Macedonia Economic \& Social Sciences, Thessaloniki, Greece. Retrieved on March 20, 2015, from https://www.researchgate.net/profile/Margarida_Abreu/publication237460076_COMMERCI AL_BANK_INTEREST_MARGINS_AND_PROFITABILITY_EVIDENCE_FOR_SOME_EU_COUNTRIE S/links/541036590cf2f2b29a3f6c67. pdf

Adjei, F. (2012). Debt dependence and corporate performance in a financial crisis: evidence from the sub-prime mortgage crisis. Journal of Economics and Finance, 36(1), 176-189. http://dx.doi.org/10.1007/s12197-010-9140-0

Athanasoglou, P. P., Brissimis, S. N., \& Delis, M. D. (2008). Bank-specific, industry-specific and macroeconomic determinants of bank profitability. Journal of International Financial Markets, Institutions and Money, 18(2), 121-136. Retrieved on September 15, 2014, from https://ideas.repec.org/p/bog/wpaper/25.html.http://dx.doi.org/10.1016/j.intfin.2006.07.0 01

Baker, S. H. (1973). Risk Leverage and Profitability: An Industry Analysis. Review of Economics and Statistics. 55 (4), 503-507. http://dx.doi.org/10.2307/1925675

Beleska-Spasova, E., Glaister, K. W., \& Stride, C. (2012). Resource determinants of strategy and performance: The case of British exporters. Journal of World Business, 47(4), 635-647. http://dx.doi.org/10.1016/j.jwb.2011.09.001

Berger, A.N., Bouwman, C.H.S.,Kick, T.K., \& Schaeck, K. ～(2014). Bank Risk Taking and Liquidity Creation Following Regulatory Interventions and Capital Support. Retrieved on June 15, 2015, from http://dx.doi.org/10.2139/ssrn.1908102.

Bernard, A. B., Jensen, J. B., \& Lawrence, R. Z. (1995). Exporters, jobs, and wages in US manufacturing: 1976-1987. Brookings Papers on Economic Activity: Microeconomics, 1995, 67-119. http://dx.doi.org/10.2307/2534772

Bhagwat, Y., \&DeBruine, M. (2011). R\&D and Advertising Efficiencies in the Pharmaceutical Industry. International Journal of Applied Economics, 8(1), 55-65.

Bourke, P. (1989). Concentration and other determinants of bank profitability in Europe, North America and Australia. Journal of Banking \& Finance, 13(1), 65-79. http://dx.doi.org/10.1016/0378-4266(89)90020-4

Chaudhuri, S. (2005). The WTO and India's pharmaceuticals industry: Patent protection, TRIPS, and developing countries. New Delhi: Oxford University Press.

Comanor, W. S., \& Wilson, T. A. (1972).Advertising market structure and performance. J. Reprints Antitrust L. \& Econ., 4(25). 
Profitability Determinants in Indian Drugs and Pharmaceutical Industry: An Analysis of ...

Confederation of Indian Industry (2014). India Pharma Inc.: Changing Landscape of Indian Pharma Industry. Retrieved on January 17, 2016, from https://www.pwc.in/assets/pdfs/publications/2013/changing-landscape-of-the-indianpharma-industry.pdf

Demir, F. (2013). Growth under exchange rate volatility: Does access to foreign or domestic equity markets matter? Journal of Development Economics, 100(1), 74-88. http://dx.doi.org/10.1016/j.jdeveco.2012.08.001

Feeny, S. (2000). Determinants of profitability: an empirical investigation using Australian tax entities. (Melbourne Institute of Applied Economic and Social Research No.1/00). Melbourne: The University of Melbourne.

Flamini, V., Schumacher, L., \& McDonald, C. A. (2009). The determinants of commercial bank profitability in Sub-Saharan Africa. (IMF Working Paper WP 09/15). Washington DC: International Monetary Fund.

Gale, B. (1972). Market Share and Rate of Return. Review of Economics and Statistics, 54 (4), 412-23. http://dx.doi.org/10.2307/1924568

Glen, J., Lee, K. \& Singh, A. (2001). Persistence of profitability and competition in emerging markets. Economics Letters, 72(2), 247-253. http://dx.doi.org/10.1016/S01651765(01)00425-6

Government of India (2012). Annual Report, Department of Pharmaceuticals, Ministry of Chemicals \& Fertilizers, New Delhi, India.

Government of India (2014). Annual Report 2013-14, Competition Commission of India, New Delhi, India.

Government of India (2014). Annual Report, Department of Pharmaceuticals, Ministry of Chemicals \& Fertilizers, New Delhi, India.

Government of India (2015). Indian Pharmaceutical Industry - A Global Industry. Department of Pharmaceuticals. , Ministry of Chemicals \& Fertilizers, New Delhi, India. Retrieved on December 24, 2015, from http://pharmaceuticals.gov.in/pharma-industry-promotion

Grazzi, M. (2012). Export and Firm Performance: Evidence on Productivity and Profitability of Italian Companies. Journal of Industry, Competition and Trade, 12(4), 413-444. http://dx.doi.org/10.1007/s10842-011-0102-9

Hurdle, G. J. (1974). Leverage Risk, Market Structure and Profitability. Review of Economics and Statistics, 56(4), 478-85. http://dx.doi.org/10.2307/1924463

Joseph, R.K. (2011). The R\&D Scenario in Indian Pharmaceutical Industry (RIS Discussion Papers No. 176). New Delhi: Research and Information System for Developing Countries.

Kambhampati, U. S., \& Parikh, A. (2003). Disciplining firms: the impact of trade reforms on profit margins in Indian industry. Applied Economics, 35(4), 461-470. http://dx.doi.org/10.1080/00036840210155177

Kiran, R., \& Mishra, S. (2011). Research and development, exports and patenting in the Indian pharmaceutical industry: A post TRIPS analysis. Eurasian Journal of Business and Economics, 4(7), 53-67.

Kongmanila, X., \& Takahashi, Y. (2009). Inter-firm cooperation and firm performance: An empirical study of the Lao garment industry cluster. International Journal of Business and Management, 4(5), 3-17. http://dx.doi.org/10.5539/ijbm.v4n5p3 
Kuntluru, S., Muppani, V. R., \& Khan, M. A. A. (2008). Financial performance of foreign and domestic owned companies in India. Journal of Asia-Pacific Business, 9(1), 28-54. http://dx.doi.org/10.1080/10599230801971259

Mahajan, V., (2015). Trade Performance, Efficiency and Productivity of Indian Drug and Pharmaceutical Industry (Unpublished doctoral dissertation) Indian Institute of Technology Roorkee, Roorke, India.

Mahajan, V., Nauriyal, D., \& Singh, S. (2014). Efficiency and Ranking of Indian Pharmaceutical Industry: Does Type of Ownership Matter? Eurasian Journal of Business and Economics, 7 (14), 29-50. https://doi.org/10.17015/ejbe.2014.014.02.

Malmberg, C. (2008). R\&D and Financial Systems: The Determinants of R\&D Expenditures in the Swedish Pharmaceutical Industry. (Paper No. 01). Centre for Innovation, Research and Competence in The Learning Economy (CIRCLE), Lund.

Mazumdar, M. (2013). An Overview of the Indian Pharmaceutical Sector. In Performance of Pharmaceutical Companies in India (pp. 17-44). Physica-Verlag HD. http://dx.doi.org/10.1007/978-3-7908-2876-4_2

McDonald, J. T. (1999). The determinants of firm profitability in Australian manufacturing. Economic Record, 75(2), 115-126. http://dx.doi.org/10.1111/j.14754932.1999.tb02440.x

Mohapatra, A. K. (2012). Determinants of Corporate Capital Structure: Evidence from Indian Industries. Asian Journal of Management, 3(1), 10-13.

Mohapatra, B. (2012). Implications of Basel III for capital, liquidity and profitability of banks. In Address by the Executive Director, Reserve Bank of India, National Conference on emerging macro environment, regulatory changes and bank competitiveness, National Institute of Bank Management, Pune, India.

Molyneux, P., \& Thornton, J. (1992). Determinants of European bank profitability: A note. Journal of banking \& Finance, 16(6), 1173-1178. http://dx.doi.org/10.1016/03784266(92)90065-8

Nauriyal, D. K., \& Sahoo, D. (2008). The new IPR regime and Indian drug and pharmaceutical industry: An empirical analysis. Paper presented at3rd Annual Conference of the EPIP Association, Bern, Switzerland.

Olweny, T., \&Shipo, M. T. (2011). Effects of Banking Pectoral factors on the profitability of commercial banks in Kenya. Economics and Finance Review, 1(5), 1-30.

Ongore, V. O., \&Kusa, G. B. (2013). Determinants of financial performance of commercial banks in Kenya. International Journal of Economics and Financial Issues, 3(1), 237-252.

Oustapassidis, K. (1998). Performance of Strategic Groups in the Greek Dairy Industry. European Journal of Marketing, 32(11/12), 962-973. http://dx.doi.org/10.1108/03090569810243578

Pradhan, J. P. (2006). Global competitiveness of Indian pharmaceutical industry: trends and strategies. ISID Working Paper No.2006/05). Gujarat: Central University of Gujarat. http://dx.doi.org/10.2139/ssrn.1413728

Prasetyantoko, A., \&Parmono, R. (2008). A Comparison of Financial Performance in the Banking Sector: Some Evidence from Omani Commercial Banks. International Research Journal of Finance and Economics, 3(1), 1-22. 
Profitability Determinants in Indian Drugs and Pharmaceutical Industry: An Analysis of ...

Said, R. M., \&Tumin, M. H. (2011). Performance and financial ratios of commercial banks in Malaysia and China. International Review of Business Research Papers, 7(2), 157-169.

San, O.T., \&Heng, T.B. (2011). Capital Structure and Corporate Performance of Malaysian Construction Sector. International Journal of Humanities and Social Science, 1(2), 28-36.

Scherer, F. M. (2001). The link between gross profitability and pharmaceutical R\&D spending. Health Affairs, 20 (5), 216-220. http://dx.doi.org/10.1377/hlthaff.20.5.216

Simanjuntak, D. G., \&Tjandrawinata, R. R. (2011). M\&A of Generic Pharmaceutical Companies Increases Productivity. Retrieved from http://dx.doi.org/10.2139/ssrn.194676

Spaventa, L. (1970). Rate of Profit, Rate of Growth, and Capital Intensity in a Simple Production Model. Oxford Economic Papers, 22(2), 129-147.

Stierwald, A. (2010). Determinants of Profitability: An Analysis of Large Australian Firms(Melbourne Institute Working Paper No. 3/10). Retrieved from http://dx.doi.org/10.2139/ssrn.1632749

Sun, K. A., \& Kim, D. Y. (2013). Does Customer Satisfaction Increase Firm Performance? An Application of American Customer Satisfaction Index (ACSI). International Journal of Hospitality Management, 35, pp.68-77. http://dx.doi.org/10.1016/j.ijhm.2013.05.008

Tyagi, S., Mahajan, V., \& Nauriyal, D. K. (2014). Innovations in Indian Drug and Pharmaceutical Industry: Have they Impacted Exports?. Journal of Intellectual Property Rights, 19, 243-252.

Uctum, M. (1995). The Evolution and Determinants of Corporate Profits: An International Comparison (Research Paper No. 9502). New York: Federal Reserve Bank.

Vassiliou, D., \&Frangouli, Z. (2000). The Banks' Profitability Concentration Relationship in the Area of Financial Integration. European Research Studies Journal, 3(3-4), 57-68.

Vijayakumar, D. (2011). An Empirical Study of Firm Structure and Profitability Relationship: The Case of Indian Automobile Firms. International Journal of Research in Commerce, IT and Management, 1(2), 84-92.

Vogel, A., \& Wagner, J. (2011). Robust estimates of exporter productivity premia in German business services enterprises. Economic and Business Review, 13(1-2), 7-26.

Vu, H., Holmes, M., Lim, S., \& Tran, T. (2014). Exports and profitability: a note from quantile regression approach. Applied Economics Letters, 21(6), 442-445. http://dx.doi.org/10.1080/13504851.2013.866197

Wagner, J. (2007). Exports and productivity: A survey of the evidence from firm-level data. The World Economy, 30(1), 60-82. http://dx.doi.org/10.1111/j.14679701.2007.00872.x

Wagner, J. (2012). Exports, imports and profitability: First evidence for manufacturing enterprises. Open Economies Review, 23(5), 747-765. http://dx.doi.org/10.1007/s11079-0119235-z

Zimmerman, K.F. (1987). Trade and Dynamic Efficiency. Kyklos, 40, 73-87. http://dx.doi.org/10.1111/j.1467-6435.1987.tb02399.x

Zubairi, H. J. (2010). An Investigation of the Influence of Key Financial and Economic Indicators on Profitability of Cement Sector Companies in Pakistan. Finance and Corporate Governance Conference. http://dx.doi.org/10.2139/ssrn.1534186. 